\title{
(Polyacrylamide-Kaolin) Composite Used For Extraction Precious Metals (Au+1, Ag+1) From Electronic Waste Solution by Using Hydrometallurgical Method
}

\author{
Raghad Hamid Hilal \\ raghadhilal4@gmail.com \\ Department of Production Engineering \& Metallurgy, University of Technology - Iraq
}

\begin{abstract}
In this study, electronic waste solution was prepared by leached amount of waste in dilute aqua regia $\left(1 \mathrm{HNO}_{3}: 3 \mathrm{HCl}\right)$. Hydrometallurgy method (solvent extraction) used to extract precious metals $\left(\mathrm{Au}^{+1}, \mathrm{Ag}^{+1}\right)$ from electronic waste by added both of mineral clay (kaolin) and (Polyacrylamide-Kaolin) composite as a adsorbent material to e- waste solution under many of different parameters. These parameters are contact time (i.e. $30 \mathrm{~min}, 60 \mathrm{~min}$, and $120 \mathrm{~min}$ ), weight in volume unit of adsorbent material (i.e. 5 , 10 and 20 g.. $\mathrm{L}^{-1}$ ) which are effects on the adsorption capacity and adsorption efficiency of adsorbent material. Results proved that the adsorption (efficiency and capacity) of Polyacrylamide-Kaolin composite relatively increased than kaolin to extract $\left(\mathrm{Au}^{+1}, \mathrm{Ag}^{+1}\right)$ ions from a neutral e-waste solution. According to the curves of adsorption (i.e. efficiency and capacity), the operation condition preferred at contact time and adsorbent material amount which are equal to $60 \mathrm{~min}$ and $10 \mathrm{~g} . \mathrm{L}^{-1}$ respectively
\end{abstract}

Keywords- electronic waste; (Polyacrylamide-Kaolin) composite; extraction hydrometallurgy; precious metals; adsorption (efficiency and capacity)

\section{INTRODUCTION}

The production of electric and electronic equipments is one of the growing global manufacturing activities. As new and more efficient electronic devices come on to the markets, a significant number of old electronic devices are being scrapped [1]. In addition, the scrapped materials included heavy metals, which considered as dangerous residue. Thus, the recycling of these scrapped materials becomes more important to prevent environmental pollution [2]. The using of electrical and electronic products had been increased in growth countries and their recycling are more beneficial for environment. Further the electronic waste (e-waste) is classified as hazardous materials and they need accurate process to deal them. However, the presence of precious metal in e-waste such as a gold, silver, nickel, zinc makes it attractive for recycling [3].

Hydrometallurgical method used as primarily process for the leaching. It involves the use of aqueous solutions containing a filtrate, which is brought into contact with a material containing a precious metal. Additionally, the metals are concentrated and purified by using precipitation, cementation, solvent extraction and ion exchange [4].

Jing-ying et al. [5] noticed that gold extraction was found to be enhanced in a PCBs particle size of 100 meshes with the solutions containing $24 \mathrm{~g} / \mathrm{L}$ thiourea and $\mathrm{Fe}^{3+}$ concentration of $0.6 \%$ under the room temperature. Patríciaetal [6] developed a recycling route of gold and silver present in a PCB using alternative reagents for cyanide, such as sodium and ammonium thiosulfate. These reagents are less harmful to the environment and worker health.

The first characterization of gold and silver was performed with aqua regia. The results show $86.26 \mathrm{~g} \mathrm{Au} / \mathrm{ton}$ of PCBs and $123.85 \mathrm{~g} \mathrm{Ag} / \mathrm{ton}$ of PCBs. The second characterization was performed with a commercial cyanide-based reagent and $112.02 \mathrm{~g} \mathrm{Au} / \mathrm{ton}$ of PCBs and $26.13 \mathrm{~g} \mathrm{Ag} /$ ton of PCBs were obtained. A leaching study with solutions based on thiosulfate was performed and an extraction of $9.02 \mathrm{~g} \mathrm{Au} / \mathrm{ton}$ of PCBs and $33.88 \mathrm{~g} \mathrm{Ag} / \mathrm{ton}$ of PCBs was obtained, compared to characterization results using a cyanide-based reagent. Behnamfard et al. [7] leached waste PCBs to recover copper, silver, gold and palladium. The recovery of copper was carried out by dissolving the sample in to a solution of sulphuric acid and hydrogen peroxide. The residues were been leached in a thiourea solution in the present of 
$\mathrm{Fe}^{3^{+}}$, recovering up to $85.76 \% \mathrm{Au}$ and $71.36 \% \mathrm{Ag}$. Abdul Khaliq et al.[8] used pyrometallurgical routes for the segregation and upgrading of PMs (gold and silver) into base metals (BMs) (copper, lead and nickel) and followed by hydrometallurgical and electrometallurgical processing for the recovery of pure base and PMs.U. Jadhav et al[9], hydrometallurgical leaching was applied to waste PCBs to design a metal recovery process. The results showed that the hydrometallurgical recovery of metals from large pieces of waste PCBs is possible. The HCl took less time for the metal recovery and was thus a very effective leaching. The use of large pieces of PCBs for metal recovery will facilitate the recycling of the remaining boards. It will also avoid the problem of precipitate contamination when recovering the metals from the leach liquors. Hence, an economical hydrometallurgical process can be established for the recovery of metals from waste PCBs. The aim of the present study increased activity of kaolin clay by addition polymeric material (polyacrylamide) via prepared composite material to removal precious metals from electronic waste solution.

\section{MATERIALS AND METHODS}

\section{- $\quad$ Materials}

In this study, the clay mineral white kaolin with chemical composition: $56.98 \%\left(\mathrm{SiO}_{2}\right), 5.69 \%\left(\mathrm{Fe}_{2} \mathrm{O}_{3}\right), 14.96 \%\left(\mathrm{Al}_{2} \mathrm{O}_{3}\right)$, $4.64 \%(\mathrm{CaO}), 1.47 \%(\mathrm{MgO})$, which supplied from Iraqi Geological Survey, has been used. Moreover, the polyacrylamide, which supplied from the Interchimiques SA France as white powder were adopted. The e-waste materials selected from printed circuit because it contains most of the elements such as lead (Pb), gold (Au), nickel (Ni), silver $(\mathrm{Ag})$, cadmium $(\mathrm{Cd})$, zinc $(\mathrm{Zn})$ and copper $(\mathrm{Cu})$, and Nitric acid \&Hydrochloric acid. The printed circuit were supplied from CDH company.

\section{- 2.1. Method}

\section{- 2.2.1 Prepared (Polyacrylamide-Kaolin) composite}

First of all, the white kaolin rocks were crushed using Jaw Crusher. Then, they grinded by using a Ball Mill for 5 min at $220 \mathrm{rpm}$. The output product is white kaolin as a powder and it has a various grain sizes, which were separated and discerned by using sieving device for $15 \mathrm{~min}$. The sieving device has the following sequence $1.16,0.212,0.075,0.063$, $0.045 \mathrm{~mm}$. Particles with dimension less than $(0.045 \mathrm{~mm})$ were chosen to mix with white powder (polyacrylamide). The mixing ratio between clay and polymeric material is 1:1and then they dissolved in the water as a matrix for the composite material. Hand molding method used for preparation of this homogeneous composite material (PAM- White kaolin clay).

\section{- 2.2.2 Prepared of electronic waste solution}

Accurately about $(5 \mathrm{~g})$ weight of the e-waste powder was treated with aqua regia in a beaker with stirring for one day. Then, the output solution was filtered and to e- waste solution. E-waste solution was $(\mathrm{pH}=3.7)$ according to the $\mathrm{pH}$ meter device. Thus, to increase the $\mathrm{pH}$ of e-waste solution to the normal conditions (i.e. $\mathrm{pH}=7$ ), many drops of $(\mathrm{NaOH})$ were added to this solution.

\subsubsection{Efficiency testing}

Samples, which consisted from white kaolin and Polyacrylamide-Kaolin and have different weight [5,10,20] g.L ${ }^{-1}$, at particle size $(0.045>\mathrm{mm})$, were mixed with $20 \mathrm{ml}$ of natural e-waste solution by magnetic stirrer at different times (i.e. $30,60,120 \mathrm{~min}$ ) and speed $300 \mathrm{rpm}$. Then, the mixture content was filtered and the remaining concentration of $\mathrm{Ag}^{+1}$, $\mathrm{Au}^{+1}$ in the output nickel solution was determined by using Flame Atomic Absorption spectrophotometer. The flowchart of experimental steps shown in Figure 1. 


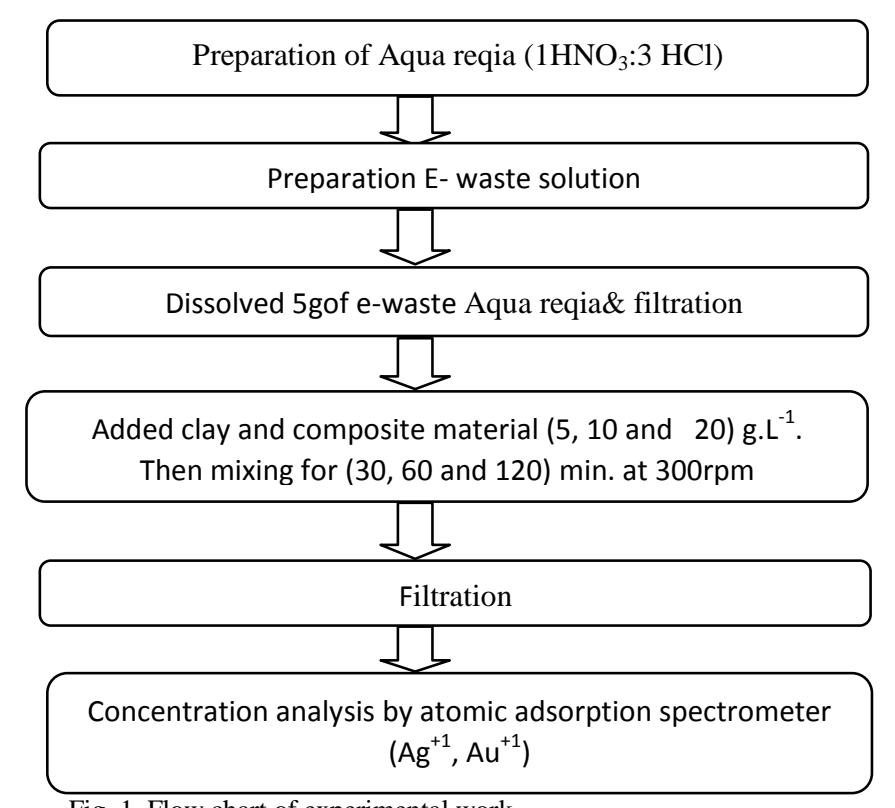

Fig. 1. Flow chart of experimental work.

The adsorption efficiency (\%) and the adsorption capacity $\left(\mu \mathrm{g} \cdot \mathrm{g}^{-1}\right)$ for the adsorption materials calculated by applying the following equations [8]:

$$
\begin{aligned}
& \text { Adsorption efficiency } \%=\left[\left(\mathrm{C}_{\mathrm{i}}-\mathrm{C}_{\mathrm{f}}\right) / \mathrm{C}_{\mathrm{i}}\right] * 100 \\
& \text { Adsorption capacity }\left(\mu \mathrm{g} \cdot \mathrm{g}^{-1}\right)=\left[\left(\mathrm{C}_{\mathrm{i}}-\mathrm{C}_{\mathrm{f}}\right) * \mathrm{~V} / \mathrm{m}\right]
\end{aligned}
$$

Where $\mathrm{C}_{\mathrm{i}}, \mathrm{C}_{\mathrm{f}}$ referred to initial and actual concentration of $\mathrm{Au}^{+1}, \mathrm{Ag}^{+1}$ respectively. $\mathrm{V}$ and $\mathrm{m}$ refereed to volume ( $\mathrm{ml}$ ) and mass $\left(\mathrm{g} . \mathrm{L}^{-1}\right)$ respectively.

\section{RESULTS AND DISCUSSION}

- 3.1 Adsorption efficiency

- 3.1.1-Effect of amount of adsorption material

Figure 2 illustrated the relation of adsorption efficiency with the amount of clay (g.L $\left.\mathrm{L}^{-1}\right)$ at fixed time $(60 \mathrm{~min})$ and $\mathrm{pH}=7$. It is noted that the behavior of the adsorption efficiency has the different directions. Firstly, for $\mathrm{Au}^{+1}$ the efficiency has a maximum value nearly (95-99) percentage at $\left(5 \mathrm{~g} \cdot \mathrm{L}^{-1}\right)$ from clay. This is referring to that the kaolin has good ability to adsorbed gold ions. Then, there was a clear decreasing when the amount of the clay increased $(60-80)$ percentage due to the de-adsorption process. Secondly, for $\mathrm{Ag}^{+1}$ ions, the maximum efficiency was attained at $\left(5 \mathrm{~g} . \mathrm{L}^{-1}\right)$ amount of the clay. Then there was a clearly decreasing, but at specific amount of adsorbent material $\left(20 \mathrm{~g} . \mathrm{L}^{-1}\right)$, adsorption efficiency values to precious metals was nearly (40-80) percentage. So, adsorption efficiency depends on the amount of adsorbent material. 


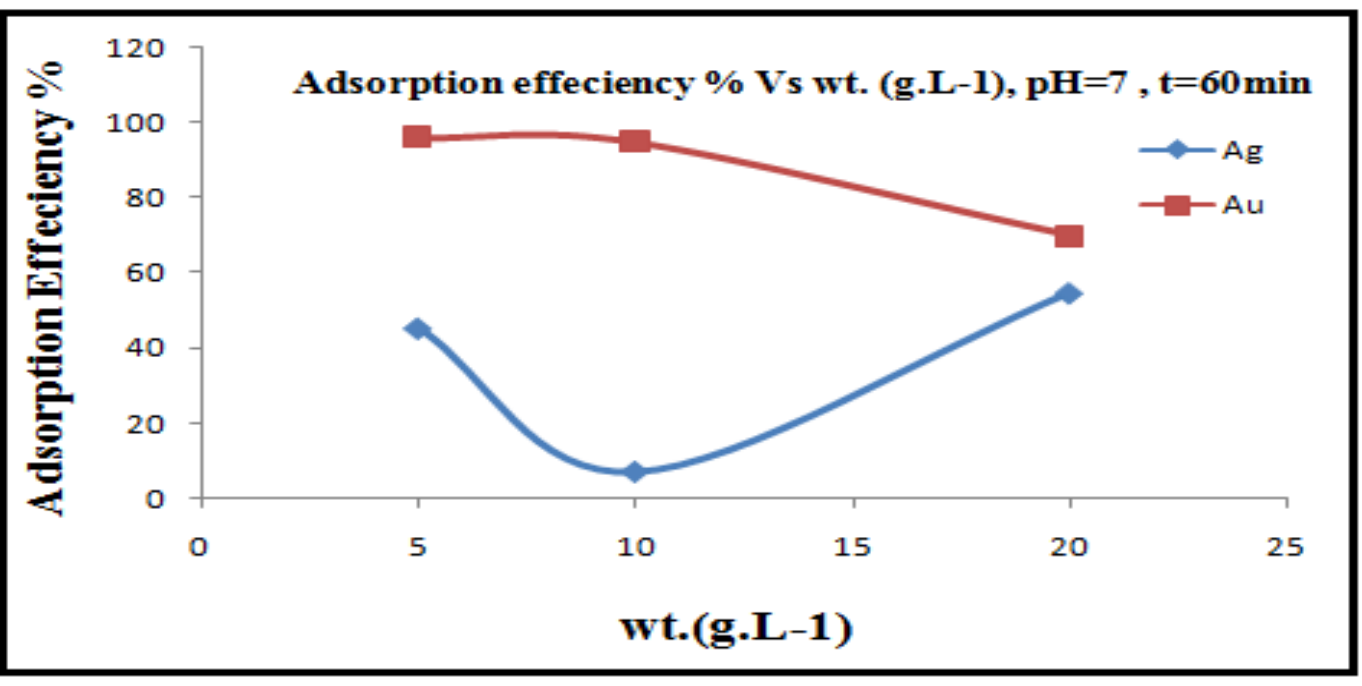

Fig. 2. The relation of adsorption efficiency with the amount of clay at fixed time (60min) and $\mathrm{pH}=7$.

Figure 3 presented the relation of adsorption efficiency with the amount of composite material at $60 \mathrm{~min}$ and $\mathrm{pH}=7$. It is noted that the behavior of the adsorption efficiency for two precious metals have the same trend. The adsorption efficiency increased with amount of composite material increase and this is due to (Polyacrylamide-Kaolin) composite has a good ability to adsorbent $\left(\mathrm{Au}^{+1}, \mathrm{Ag}^{+1}\right)$ ions from neutral electronic wastes solution. Adsorption efficiency values are intersect at $\left(10 \mathrm{~g} . \mathrm{L}^{-1}, 93.5 \%\right)$. Then it was nearly stable. This is confirm that the adsorption efficiency independent on the amount of composite material.

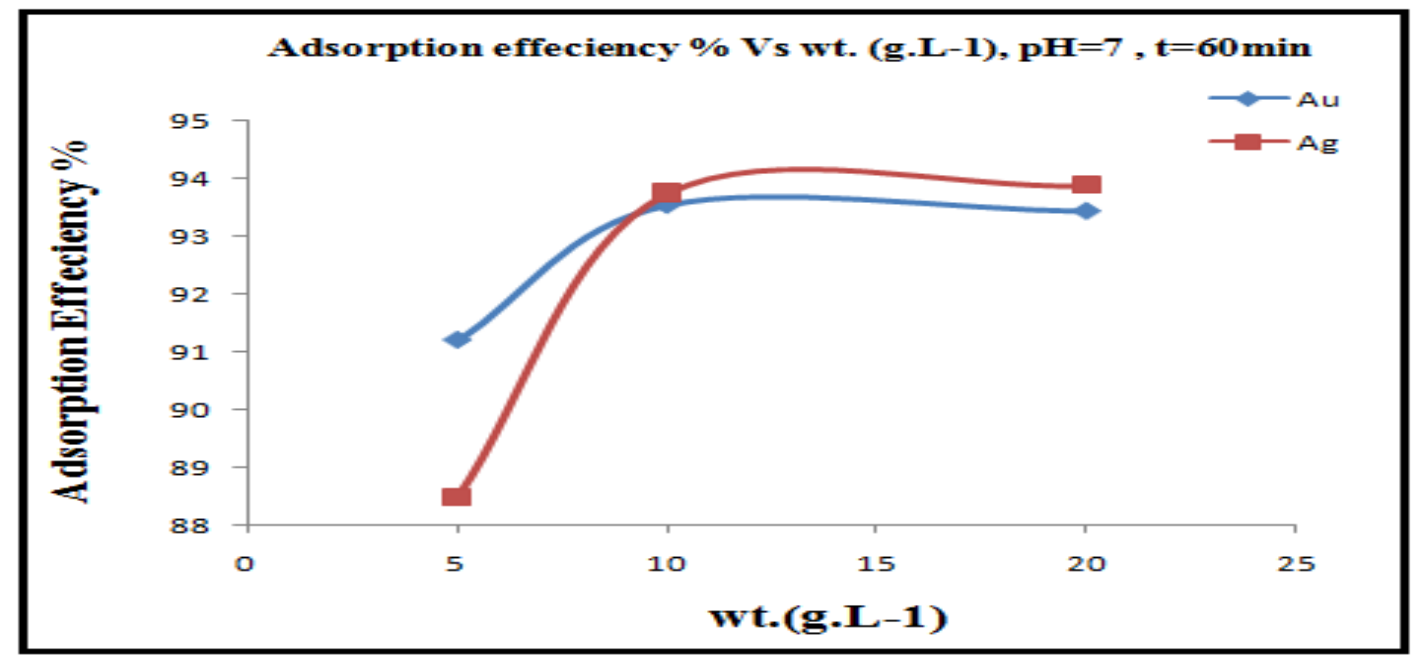

Fig. 3. The relation of adsorption efficiency with the amount of composite material at fixed time (60min) and $\mathrm{pH}=7$.

\section{- 3.1.2 Effect of contact time}

Figure 4 showed the relation of adsorption efficiency with contact time at fixed amount of clay $\left(10 \mathrm{~g} . \mathrm{L}^{-1}\right)$ and $\mathrm{pH}=7$. It can be seen that the adsorption efficiency of $\mathrm{Ag}^{+1}$ was decreased slowly with increasing time till $\mathrm{t}=60 \mathrm{~min}$, then it 


\section{IS Wasit Journal \\ of Engineering Sciences}

VOLUME: ( 7 ), NO.: ( 3 ) 르미

became constant even with increasing time. However, the $\mathrm{Au}^{+1}$ adsorption efficiency began to increase with increasing time then it decreased with increasing time. This is referred to the kaolin has equilibrium adsorption property to precious metals and adsorption efficiency independent of the time.

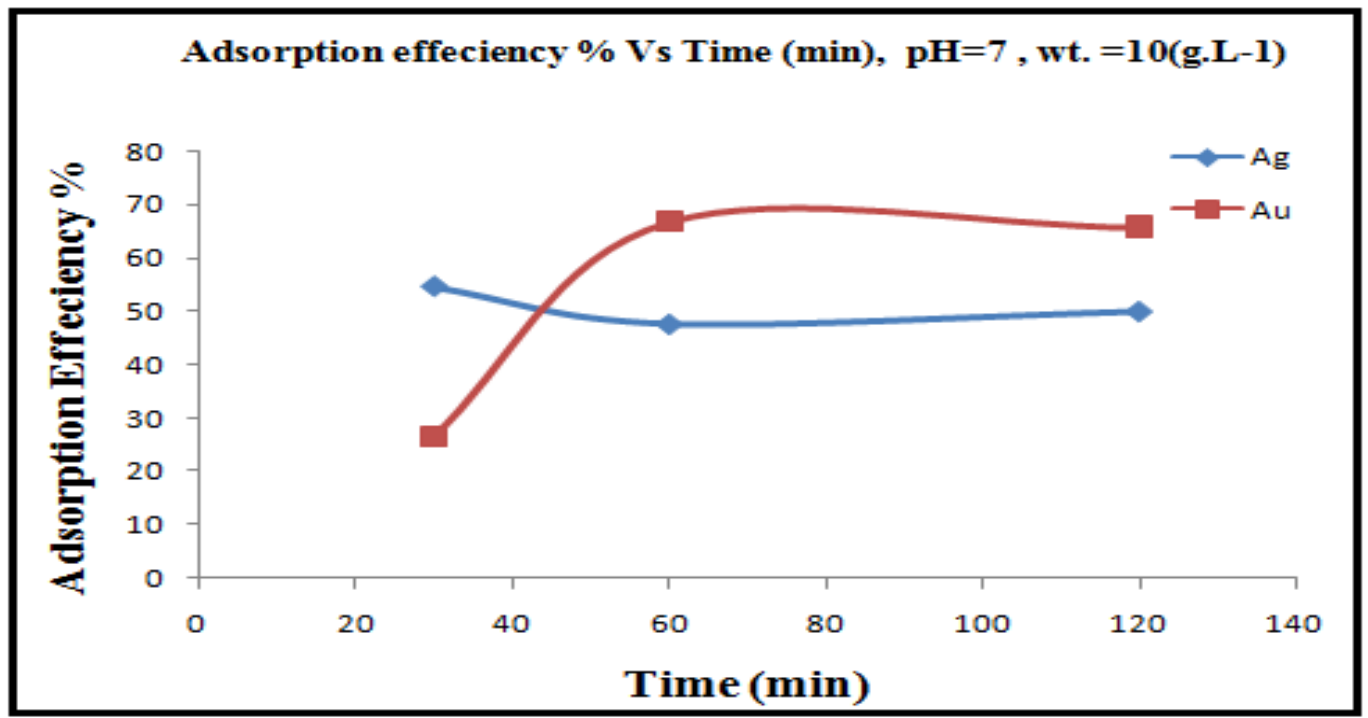

Fig. 4. The relation of adsorption efficiency with contact time at fixed amount of clay $\left(10 \mathrm{~g} \cdot \mathrm{L}^{-1}\right)$ and $\mathrm{pH}=7$.

Figure 5 presented the relation of adsorption efficiency with contact time at fixed amount of composite material (10g.L ${ }^{1}$ ) and $\mathrm{pH}=7$.It can be clearly noticed that the adsorbent material has high efficiency to adsorbent $\mathrm{Ag}^{+1}$ than $\mathrm{Au}^{+1}$ but it was stable as a straight line. Adsorption efficiency was almost independent on the contact time.

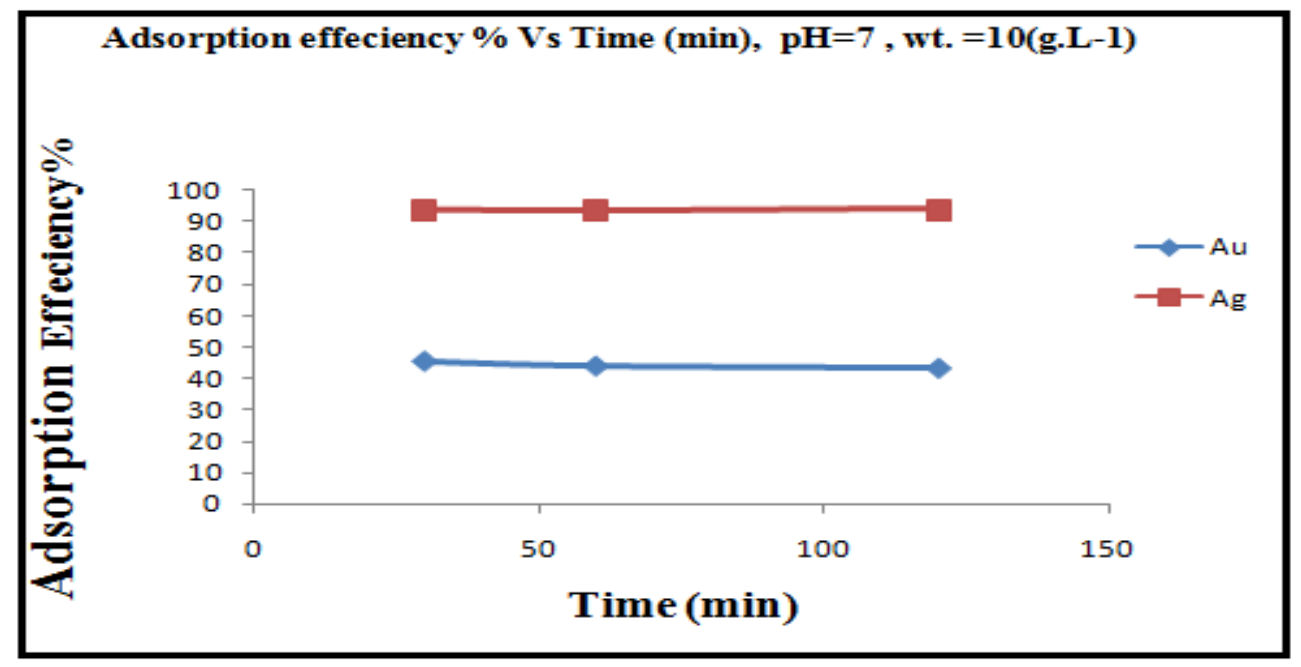

Fig. 5. The relation of adsorption efficiency with contact time at fixed amount of composite material $\left(10 \mathrm{~g} . \mathrm{L}^{-1}\right)$ and $\mathrm{pH}=7$. 
- 3.2 Adsorption capacity

- 3.2.1Effect of amount of adsorption material

Figure 6 showed that the relation of adsorption capacity with the amount of clay $\left(\mathrm{g} \cdot \mathrm{L}^{-1}\right)$ at $60 \mathrm{~min}$ and $\mathrm{pH}=7$. Clearly observed that the adsorption capacity have the same direction for two precious ions. Adsorption capacity of clay to $\mathrm{Au}^{+1}$ is more stable than $\mathrm{Ag}^{+1}$ ion. De-adsorption process led to decrease adsorption capacity when amount of clay increased until $10 \mathrm{~g} . \mathrm{L}^{-1}$ then it was increased result of increasing of clay-reinforced ability to adsorbent $\mathrm{Ag}^{+1}$ ion.

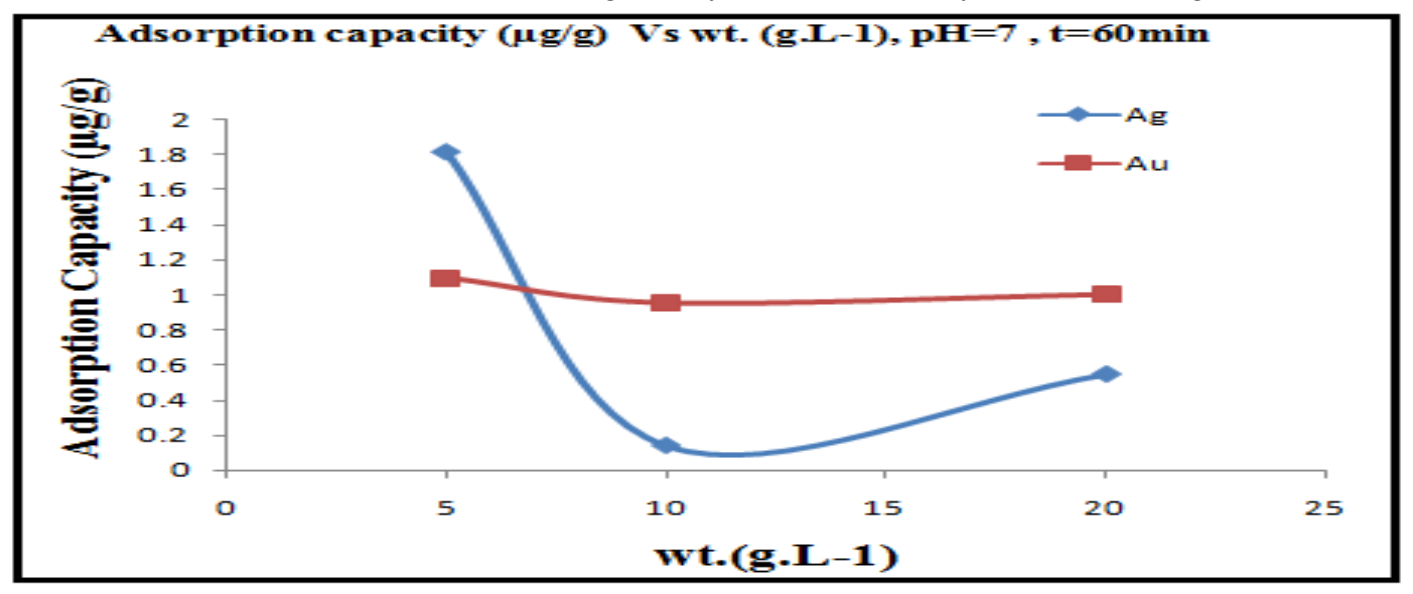

Fig. 6. The relation of adsorption capacity with the amount of clay at fixed time (60min) and $\mathrm{pH}=7$.

Figure 7 presented the relation of adsorption capacity with the amount of composite material at fixed time 60min and $\mathrm{pH}=7$. Adsorption capacity of $\mathrm{Au}^{+1}$ is independent on the amount of composite material. Meanwhile the de-adsorbent process affected on the Adsorption capacity of $\mathrm{Ag}^{+1}$, then it was increased but it remained less than $\mathrm{Ag}^{+1}$.

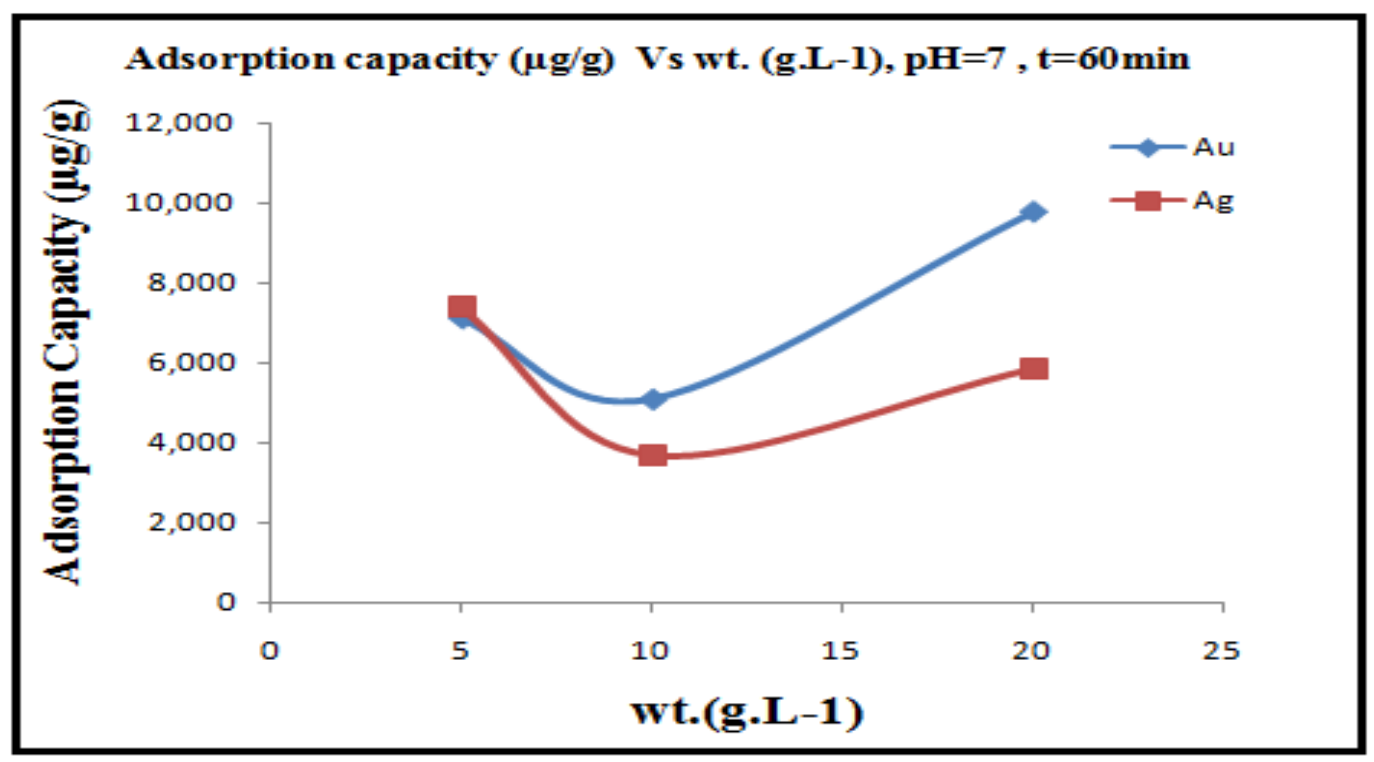

Fig. 7. The relation of adsorption capacity with the amount of composite material at fixed time (60min) and pH=7. 
- 3.2.2 Effect of contact time

Figure 8 showed that the relation of adsorption capacity with contact time at fixed amount of clay $\left(10 \mathrm{~g} \cdot \mathrm{L}^{-1}\right)$ and $\mathrm{pH}=7$. It can be seen that the adsorption capacity of two precious ions at $\mathrm{t}=60 \mathrm{~min}$ are independent with increasing time and this was because of adsorption capacity value are nearly.

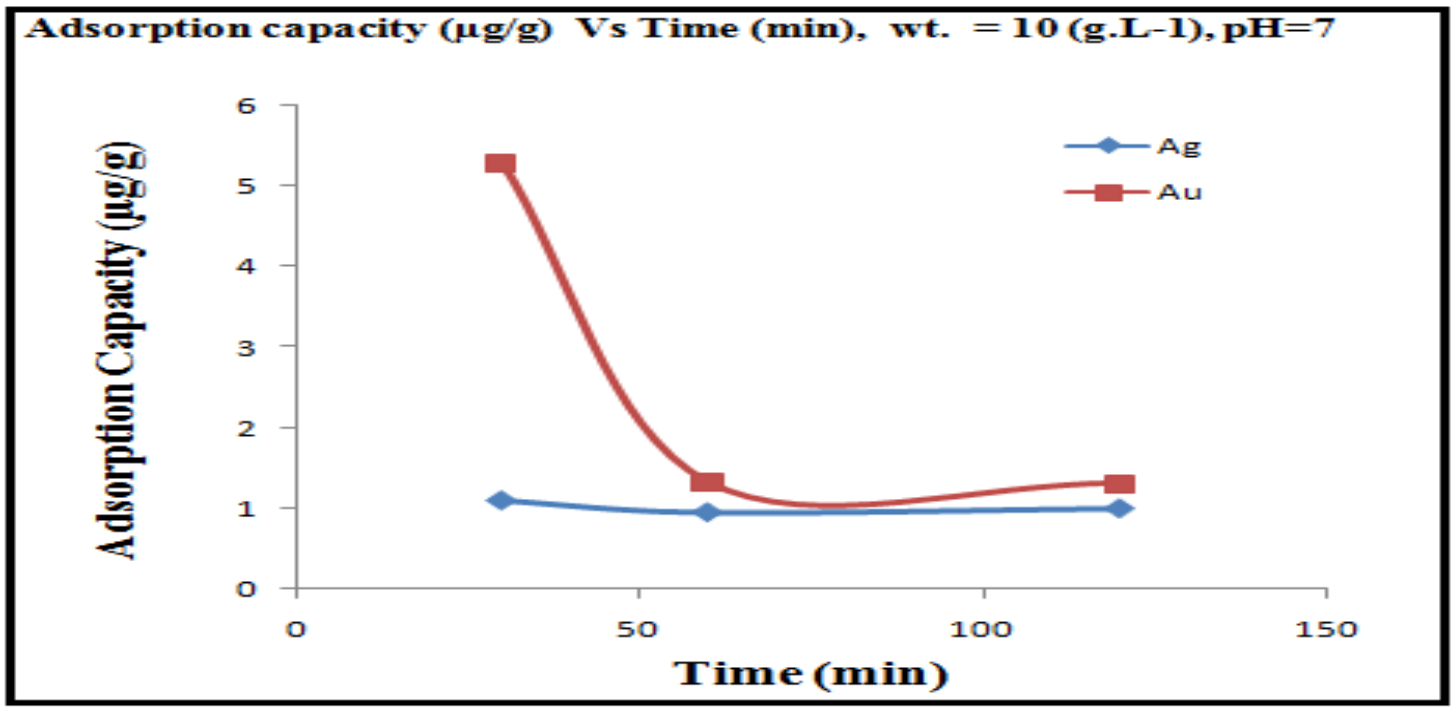

Fig. 8. The relation of adsorption capacity with contact time at fixed amount of clay $\left(10 \mathrm{~g} . \mathrm{L}^{-1}\right)$ and $\mathrm{pH}=7$.

Figure 9 presented that the relation of adsorption capacity with contact time at fixed amount of composite material (10g.L-1) and $\mathrm{pH}=7$. It can be noticed that the rate adsorption capacity was increased slightly with increasing of time. So that, the adsorption capacity dependent on time.

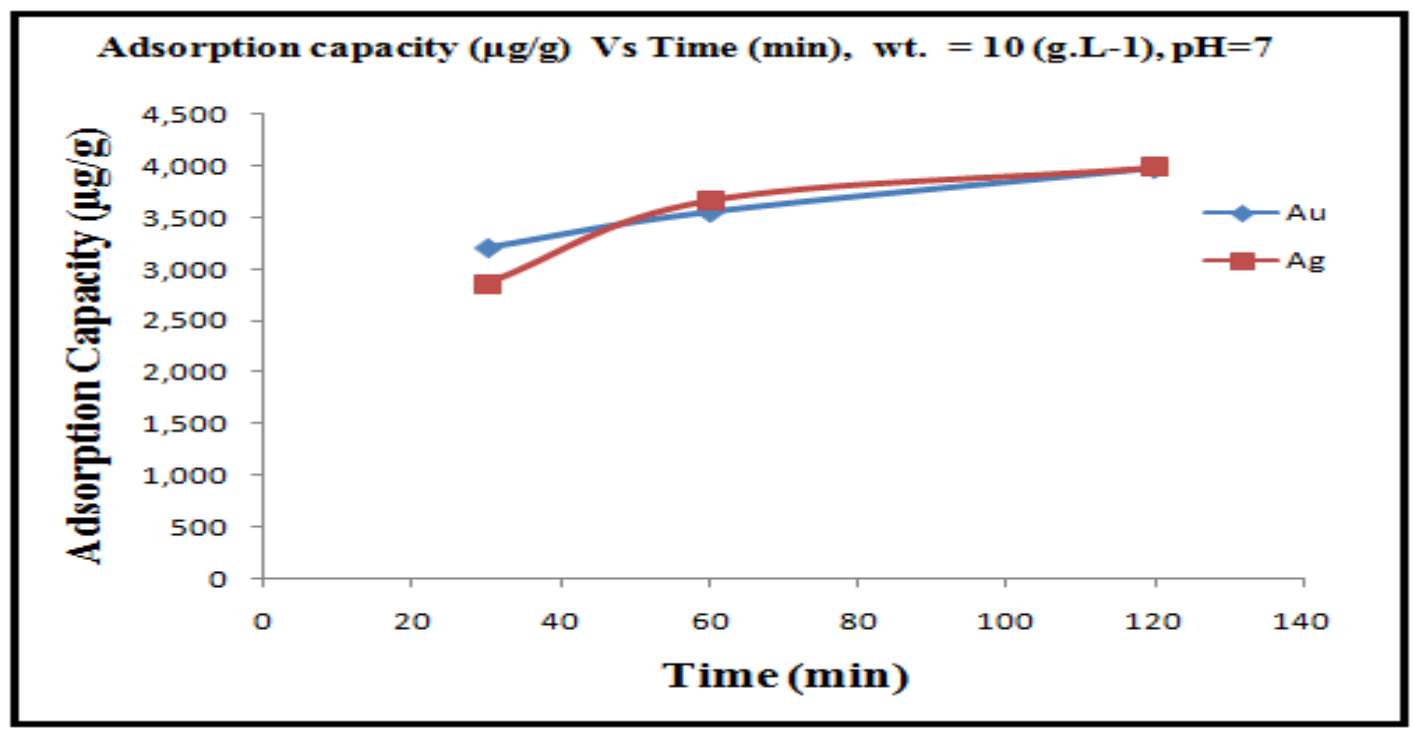

Fig. 9. The relation of adsorption capacity with contact time at fixed amount of composite material $\left(10 \mathrm{~g} \cdot \mathrm{L}^{-1}\right)$ and $\mathrm{pH}=7$. 
In addition, this study was compared with previous studies [6,9], where it was found that the amount of adsorbent material factors was affected by the susceptibility of adsorption of precious metals compared to the factor of time

\section{CONCLUSIONS}

In this study, the following conclusions are drawn:

1- Prepare effective mixture from Polyacrylamide and Kaolin with mixing ratio 1:1 for extraction heavy (precious) metals from neutral electronic waste solution.

2- The adsorption (efficiency and capacity) values for composite material were more improvement than the clay.

3- The composite of Polyacrylamide and Kaolin) reduced the dependency of the process on the operating conditions.

The adsorption (efficiency \& capacity) were significantly affected by the mount of the sorbent materials (i.e. clay and composite) rather than the time factor.

\section{NOMENCLATURE}

\begin{tabular}{|c|c|}
\hline Symbol & Definition \\
\hline e-waste & Electronic waste \\
\hline PCBs & Printed circuit boards \\
\hline PMs & Precious metals \\
\hline BMs & Base metals \\
\hline rpm & Revolution per minute \\
\hline PAM & Polyacrylamide \\
\hline pH & -Log $\left[\mathrm{H}^{+}\right]$ \\
\hline
\end{tabular}

\section{REFERENCES}

1- Santhanam N., Melvin S., Ramalingam C.," Electronic waste - an emerging threat to the environment of urban India", J Environ Health Sci Eng, V.12,2014.

2- Muibat O.F., Veronica M. N., Olubukola O. B."Heavy Metal Pollution from Gold Mines: Environmental Effects and Bacterial Strategies for Resistance", J Environ Health Sci Eng,V.13(11), 2016.

3- Martin O., " Electronic Waste Management in Ghana - Issues and Practices", Chapter (PDF Available), July 2012.

4- Koen B., Peter T.J., "Solvometallurgy: An Emerging Branch of Extractive Metallurgy", J. Sustainable Metallurgy, V.3, No.3, 2017.

5- Jing-ying L, Xiu-li X, Wen-quan L, "Thiourea leaching gold and silver from the printed circuit boards of waste mobile phones", Waste Manag., 32(6),2012.

6- Patrícia M. H.' Hugo M. V.' Andréa M. B. " "Leaching of gold and silver from printed circuit board of mobile phones", Waste Manag., Rev. Esc. Minas v.68, no.1, 2015. 
7- Behnamfard, Salarirad, Veglio , "Process development for recovery of copper and precious metals from waste printed circuit boards with emphasize on palladium and gold leaching and precipitation", Nov;33(11), 2013:2354-63.

8- Abdul Khaliq, "Muhammad Akbar Rhamdhani, Geoffrey Brooks,Syed Masood, " Metal Extraction Processes for Electronic Waste and Existing Industrial Routes: A Review and Australian Perspective", Resources, Vol.3, no. $1,2014$.

9- JadhavU. and HochengH., " Process development for recovery of copper and precious metals from waste printed circuit boards with emphasize on palladium and gold leaching and precipitation", Scientific Reports volume5, Article number: 14574 (2015). 